\title{
Assessment of liver stiffness in patients with HCV and mixed cryoglobulinemia undergoing rituximab treatment
}

\author{
Cristina Stasi ${ }^{1,2^{*}}$, Elisa Triboli ${ }^{1,2}$, Umberto Arena ${ }^{1,2}$, Teresa Urraro ${ }^{1,2}$, Antonio Petrarca ${ }^{1,2}$, Laura Gragnani ${ }^{1,2}$, \\ Giacomo Laffi, ${ }^{1,2}$ and Anna Linda Zignego ${ }^{1,2}$
}

\begin{abstract}
Introduction: Mixed cryoglobulinemia (MC) is a HCV-related lymphoproliferative disorder generally associated with advanced liver disease. Liver stiffness has been significantly correlated with histopathological stage of fibrosis. Moreover, it was influenced by necroinflammatory activity. Rituximab (RTX) is a chimeric anti-CD20 monoclonal antibody inducing transient B lymphocytes depletion that was shown to be useful and safe in the majority of HCV MC patients, leading also to improvement of cirrhotic syndrome. Aim of this study was to evaluate the modifications of liver stiffness following RTX treatment in HCV-related MC patients.
\end{abstract}

Materials and methods: Fourteen consecutive patients (10 F, 4 M; mean age $60.43 \pm 43$ ) with HCV-related chronic hepatitis $(n=10)$ or cirrhosis $(n=4)$ and MC, eligible for RTX treatment, were prospectively enrolled. Intravenous injection of $1 \mathrm{~g}$ of RTX was performed at day 0 and at day 15. Assessment of stiffness was carried out by Fibroscan ${ }^{\oplus}$ (Echosens, Paris-France) at baseline, 15 days after the first infusion, and at month 1, 3 and 6 after therapy.

Results: MC symptoms significantly improved during the study, especially during the first 3 months. Liver stiffness observed 3 months after treatment was significantly reduced when compared with pre-treatment values $(p=0.01)$. This difference disappeared after 6 months of follow-up. Cytofluorimetric analysis showed a decrease of CD19+ peripheral blood cells, with the nadir at month 3 after therapy and B cell compartment reconstitution after 6 months.

Conclusion: This study, for the first time showed that RTX-treatment in HCV-related MC induces a reduction of liver stiffness that is strictly associated with the B-cell depletion.

Keywords: Hepatitis C virus infection, Elastography, Rituximab, Mixed cryoglobulinemia

\section{Introduction}

It is known that Hepatitis $\mathrm{C}$ virus (HCV) can infect mononuclear cells [1-3] and is associated with several autoimmune/lymphoproliferative disorders, whose prototype is mixed cryoglobulinemia (MC) [4]. MC is a both autoimmune and B-cell lymphoproliferative disorder characterized by immune complexes that reversibly precipitate at low temperature (cryoglobulins). A striking association between $\mathrm{HCV}$ and $\mathrm{MC}$ was shown [5,6]: $\mathrm{HCV}$ infection was detected in a percentage from $70 \%$ to $>90 \%$ of $\mathrm{MC}$

\footnotetext{
* Correspondence: cristina.stasi@gmail.com

${ }^{1}$ Interdepartmental Center for Systemic Manifestations of Hepatitis Viruses MASVE, University of Florence, Florence, Italy

${ }^{2}$ Department of Experimental and Clinical Medicine, University of Florence, Largo Brambilla 3, 50134 Florence, Italy
}

patients and cryoglobulins in about half of $\mathrm{HCV}$ patients $[7,8] . \mathrm{MC}$ is a benign, but pre-lymphomatous condition whose clinical manifestations - the so-called mixed cryoglobulinemia syndrome, observed in a minority of total $\mathrm{MC}$ cases - are secondary to a systemic vasculitis of the small/medium size vessels [9]. It has been shown that MC can evolve to non-Hodgkin lymphoma (NHL) in $5-10 \%$ of patients without anti-HCV terapy [9] and that the overall risk of NHL in patients with $\mathrm{MC}$ is about 35 times higher than in the general population [10]. Among the most common symptoms, there are fatigue, arthralgias and purpura (Meltzer's triad). Most severe cases are associated with impairment of the kidney and central and/or peripheral nerves $[8,11]$. Anti-HCV therapy with pegylated interferon (Peg-IFN) and ribavirin (RBV) is considered the first 
therapeutic option in the treatment of mild to moderate HCV-related MC syndrome [12].

When therapy is contraindicated or not tolerated (i.e, for the severity of disease, advanced age, general clinical conditions), other therapeutic options are chosen, including, for first, immunosuppressant and antiflogistic drugs [12]. During the last decade, increasing importance was attributed to the use of the B-cell specific immunosuppressant Rituximab (RTX) [13]. RTX is a chimeric monoclonal antibody that binds to CD20 antigen on the B cell surface determining their depletion, with reconstitution generally starting from the sixth month [14]. Petrarca et al. [15] previously showed that therapy with RTX is not burdened by significant liver toxicity also when administered to patients with advanced liver disease. More interestingly, it was shown that in patients with HCV MC and clinically evident cirrhosis, RTX was able to induce improvement of cirrhosis syndrome, with Child-Pugh score reduction [15]. The reasons for such an observation are at present unknown. Transient elastography (TE) has been proposed as a possible tool for diagnosis and monitoring of nonsignificant fibrosis or severe fibrosis/cirrhosis in patients with chronic HCV infection [16-18]. Liver stiffness values have been significantly correlated with histopathological staging of liver biopsy, with excellent diagnostic accuracy in distinguishing absent/mild and advanced fibrosis [19,20], though Arena et al. showed that liver stiffness was influenced by necro-inflammatory activity [16].

Aim of this study was to evaluate the change of liver stiffness values during and after treatment with RTX in patients with HCV MC.

\section{Materials and methods}

Fourteen consecutive patients with chronic liver disease and HCV type II MC (10 women and 4 men) for whom the antiviral treatment was contraindicated or not tolerated, were consecutively enrolled at the MASVE Center outpatient clinic, University of Florence, Florence, Italy.

$\mathrm{MC}$ syndrome was diagnosed according to previously described criteria [15,21]. Serum cryoglobulin levels and characterization, levels of complement fractions, rheumatoid factor, and autoantibodies were evaluated as described [22-24]. The mean duration of MC was 40.14 months (range, 7-174 months). The most relevant clinical manifestations are listed in Table 1.

The diagnosis of liver disease was performed according to standard (histologic and/or clinical and ultrasound) criteria $[25,26]$. A diagnosis of liver cirrhosis, according to histological and/or clinical and ultrasound data, was made in 5 patients.

The nature of the study was explained to patients, who provided written informed consent before the beginning of the study, in accordance with the principles of the Declaration of Helsinki (revision of Edinburgh, 2000),
Table 1 Principal mixed cryoglobulinemia manifestations (clinical and biohumoral) diagnosed before treatment with rituximab and 3 months after therapy

\begin{tabular}{lcc}
\hline MC manifestations & $\begin{array}{c}\text { Pre-treatment } \\
(\%)\end{array}$ & $\begin{array}{c}\mathbf{3} \text { months } \\
(\%)\end{array}$ \\
\hline Clinical & $11(78.56)$ & $1(7.1)$ \\
Purpura & $13(92.96)$ & $4(28.57)$ \\
Arthralgias & $7(50)$ & $3(21.43)$ \\
Neuropathic symptoms & $2(14.28)$ & $1(7.1)$ \\
Renal involvment & $1(7.1)$ & 0 \\
Skin ulcers & $7(50)$ & $5(37.71)$ \\
Sicca syndrome & & $1.46(0-6)$ \\
Biohumoral & $3.36(1-12)$ & $10(71.43)$ \\
Cryocrit & $12(85.71)$ & $5(37.71)$ \\
Rheumatoid factor & $9(64.3)$ & \\
Reduced C4 & &
\end{tabular}

and the study was approved by the University of Florence Ethics Committee.

The patients were prospectively enrolled according to the following inclusion criteria: presence of detectable HCV-RNA; eligibility for RTX treatment; no antiviral or immunosuppressive therapies (at least in the 6 months prior to enrolment); abnormal levels of liver enzymes; exclusion of Child-B/C cirrhosis; absence of hepatocellular carcinoma and acute viral hepatitis ( $<6$ months); no coinfection with hepatitis B virus or human immunodeficiency virus, metabolic liver disease, vascular disease of the liver and biliary tract disorders; absence of an average daily alcohol consumption $>50 \mathrm{~g} /$ day or use of hepatotoxic drugs; absence of clinical conditions potentially affecting $\mathrm{TE}$, i.e. cardiac failure, and absence of physiological states contraindicated for this technique (i.e. pregnancy).

The administration of RTX was done according to the following regimen: intravenous infusion of $1 \mathrm{~g}$ at day 0 and at day 15. Before infusion, the patients received a pre-medication with acetaminophen, dexchlorpheniramine maleate and allopurinol. The concomitant use of steroids in high doses would be allowed only in case of hypersensitivity.

\section{Hepato-virological evaluation}

The determination of HCV RNA in serum samples were performed by HCV-RNA Amplicor Monitor quantitative assay (Roche Diagnostics, Basel, Switzerland; limit of detection: $15 \mathrm{IU} / \mathrm{ml}$ ), and the HCV RNA genotyping by INNO-LiPA HCV II, Immunogenetics, Gent, Belgium, according to the manufacturer instructions.

The degree of liver function was evaluated through biohumoral liver function tests (Alanine transaminase ALT, Albumin, Alkaline phosphatase, Aspartate transaminase - AST, Bilirubin, Gamma-glutamyl transpeptidase, 
Table 2 Principal demographic and hepato-virological data of the 14 HCV-positive patients with mixed cryoglobulinemia before and 3 months after treatment with rituximab

\begin{tabular}{|c|c|c|c|c|}
\hline Parameter & Baseline & 3 months & Normal range & $P$ value \\
\hline Age (years) & $60.43 \pm 43$ & & Normal range & \\
\hline Gender (M\%) & 28.5 & & & \\
\hline $\mathrm{BMI}$ & $26.24 \pm 1.74$ & & $18-25$ & \\
\hline Platelets $\left(\times 10^{9} / \mathrm{L}\right)$ & $145.50 \pm 71.22$ & $163.4 \pm 19.89$ & $140-440$ & $p=0.03$ \\
\hline $\operatorname{RBC}\left(\times 10^{12} / \mathrm{L}\right)$ & $4255 \pm 438$ & $4369 \pm 723$ & $4200-5400$ & $p=0.11$ \\
\hline WBC $\left(\times 10^{9} / \mathrm{L}\right)$ & $4684 \pm 1374$ & $4829 \pm 1898$ & $4-10$ & $p=0.86$ \\
\hline $\operatorname{ALT}(U / L)$ & $64.09 \pm 39.66$ & $65.63 \pm 35.92$ & $5-40$ & $p=0.86$ \\
\hline AST $(U / L)$ & $69.54 \pm 56.60$ & $74.81 \pm 40.78$ & $5-40$ & $p=0.08$ \\
\hline GGT (U/L) & $66.09 \pm 94.47$ & $47.09 \pm 30.03$ & $10-40$ & $p=0.38$ \\
\hline Creatinine (mg/dL) & $0.70 \pm 0.19$ & $0.65 \pm 0.15$ & $0.6-1.5$ & $p=0.40$ \\
\hline Glucose (mg/dL) & $92.66 \pm 11.58$ & $92.33 \pm 6.12$ & $65-110$ & $p=0.32$ \\
\hline Albumine (g/dL) & $3.82 \pm 0.35$ & $4.05 \pm 0.41$ & $3.5-5.0$ & $p=0.02$ \\
\hline Bilirubin (mg/dL) & $0.88 \pm 0.55$ & $1.53 \pm 1.99$ & $0,3-1$ & $p=0.13$ \\
\hline HCV-RNA (UI/L) & $719798 \pm 677364$ & $1469311 \pm 1576236$ & Undetectable & $p=0.07$ \\
\hline Genotype 1 & 11 & & & \\
\hline Genotype $2 a / 2 c$ & 2 & & & \\
\hline Genotype 3 & 1 & & & \\
\hline CC polymorfism of IL-28- $\beta$ & $27.27 \%$ & & & \\
\hline Mean stiffness (kPa) & $20.44 \pm 17.29$ & $17.00 \pm 16.05$ & & $p=0.03$ \\
\hline$C D 19+\left(10^{6} \mathrm{~L}\right)$ & $124.2 \pm 56.15$ & $38 \pm 16.59$ & & $p=0.04$ \\
\hline
\end{tabular}

Abbreviations: BMI Body mass index, RBC Red blood cells, WBC White blood cells, ALT Alanine transaminase, AST Aspartate aminotransferase, GGT Gamma glutamyl-transpeptidase. Statistically significant $\mathrm{p}$ values are labeled with bold text.

Lactic dehydrogenase, prothrombin time) and using the Child-Pugh score, as previously shown [27].

Liver biopsy was performed in 3 patients in order to confirm the fibrosis stage of liver disease. The patients underwent a measurement of liver stiffness by TE and ultrasound-guided percutaneous liver biopsy on the same day. Liver biopsy was performed on the right lobe of the liver, with a 16-gauge semiautomatic modified Menghini needle system (BIOMOL; Hospital Service, Aprilia, Italy) under local anaesthesia. Liver specimens were formalinfixed and paraffin-embedded for histological evaluation. Sections of liver tissue were stained with hematoxylin and eosin and sirius red, and examined by an experienced pathologist unaware of the results of liver stiffness. All liver specimens had a length $>25 \mathrm{~mm}$ and included at least 11 complete portal tracts, reflecting adequate standards [28]. Fibrosis (F) was staged on a five-point scale according to METAVIR. Necro-inflammatory activity (A) was also graded on a four-point scale according to the method proposed by the Metavir Cooperative Study Group [25].

The patients were evaluated by TE (FibroScan, Echosens, Paris-France), according to the manufacturer instructions, in the right intercostal spaces, before treatment with RTX, 15 days after the first infusion, at month 1, 3 and 6 after the end of therapy.
The median values of ten successful acquisitions, expressed in kilopascal $(\mathrm{kPa})$, were considered representative of the liver stiffness. Only procedures with 10 successful acquisitions, with a success rate of at least $60 \%$, and an interquartile range (IQR) lower than $30 \%$ of the median value were considered reliable.

\section{IL28B genotyping}

IL28B genotyping was performed on DNA extracted by whole blood samples, using a specific custom TaqMan SNP-Genotyping Assay (Single Nucleotide Polymorphism (SNP): rs12979860; Applied Biosystem, Foster City, CA, USA) based on allele-specific dual-labelled probes on a Rotor Gene 6000 (Corbett Research, Sidney, Australia) [29].

\section{CD19+ B cell count assessment}

The levels of B cells were evaluated through CD19+ cells count, at baseline, at month 1, 3 and 6 after RTX treatment, according to other evaluated parameters. The test was performed using a routine method by a Coulter ${ }^{\oplus}$ Lh 700 Series Hematology Analyzer (Beckman Coulter).

\section{Statistical analysis}

All results were expressed as mean \pm standard deviation. The numerical comparison of continuous data was 
performed using the Wilcoxon signed-ranks test applied to two-sample, matched pairs. Statistical significance was set at a value of $\mathrm{p}<0.05$. Statistical analysis were obtained using statistical software Stata 11, (College Station, TX, USA) and SPSS v18 (SPSS Inc., Chicago, IL, USA ).

\section{Results}

\section{Hepato-virological evaluation}

The main parameters of the study population at baseline and at month 3 after treatment are summarized in Table 2.

All patients scored anti-HCV and HCV RNA positive. The mean viral count doubled at 3 months. Eleven patients were infected by HCV genotype 1,2 patients by genotype $2 \mathrm{a} / 2 \mathrm{c}$ and the remaining one by genotype $3 \mathrm{a}$. Concerning the determination IL28B genotypes, the C/C allele was determined in 3 patients (27.27\%), while the other patients scored positive for the $\mathrm{C} / \mathrm{T}$ or $\mathrm{T} / \mathrm{T}$ alleles.
A liver biopsy was performed in 3 patients before treatment. In these patients stiffness values $(7.4,11.80$, and $17.50 \mathrm{kPa})$ reflected high necro-inflammatory activity in 2 cases (A2 F0, A2 F0, METAVIR score), and a cirrhosis in the remaining one.

\section{Liver stiffness and CD19+ levels before, during and after rituximab treatment}

In the study population, the mean stiffness values before treatment were $20.44 \pm 17.29 \mathrm{kPa}$ and the mean CD19+ levels $124.2 \pm 56.15 \times 10^{6} \mathrm{~L}$ (Table 2).

The patterns of liver stiffness during the study underwent changes that appeared related to the CD19+ levels (Table 2). Briefly: the stiffness values gradually decreased after therapy and were significantly lower three months after the end of treatment $(\mathrm{p}=0.03)$. This was paralleled by the reduction of CD19+ levels (B-cell depletion) $(\mathrm{p}=$ 0.04), (Figures 1 and 2). Six months after treatment the
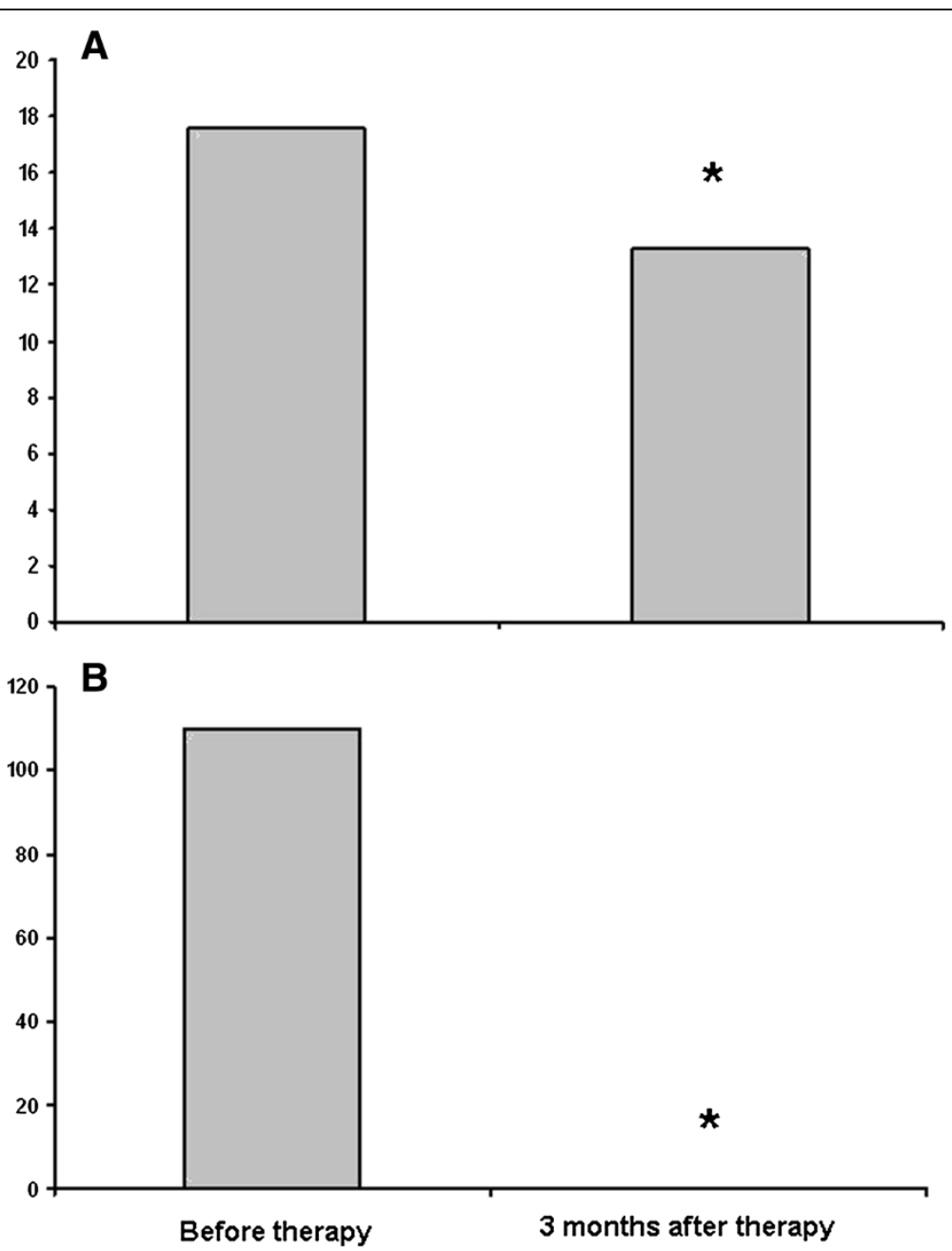

Figure 1 Changes of liver stiffness values and CD19+ cell levels at baseline and at three months after the end of treatment in a singol patient. Liver stiffness values (17.6 kPa before treatment vs 13.3 at month 3 after treatment) (panel A) and CD19+ levels $\left(110 \times 10^{6} \mathrm{~L}\right.$ before treatment vs $0 \times 10^{6} \mathrm{~L}$ at month 3 after treatment) (panel B). 

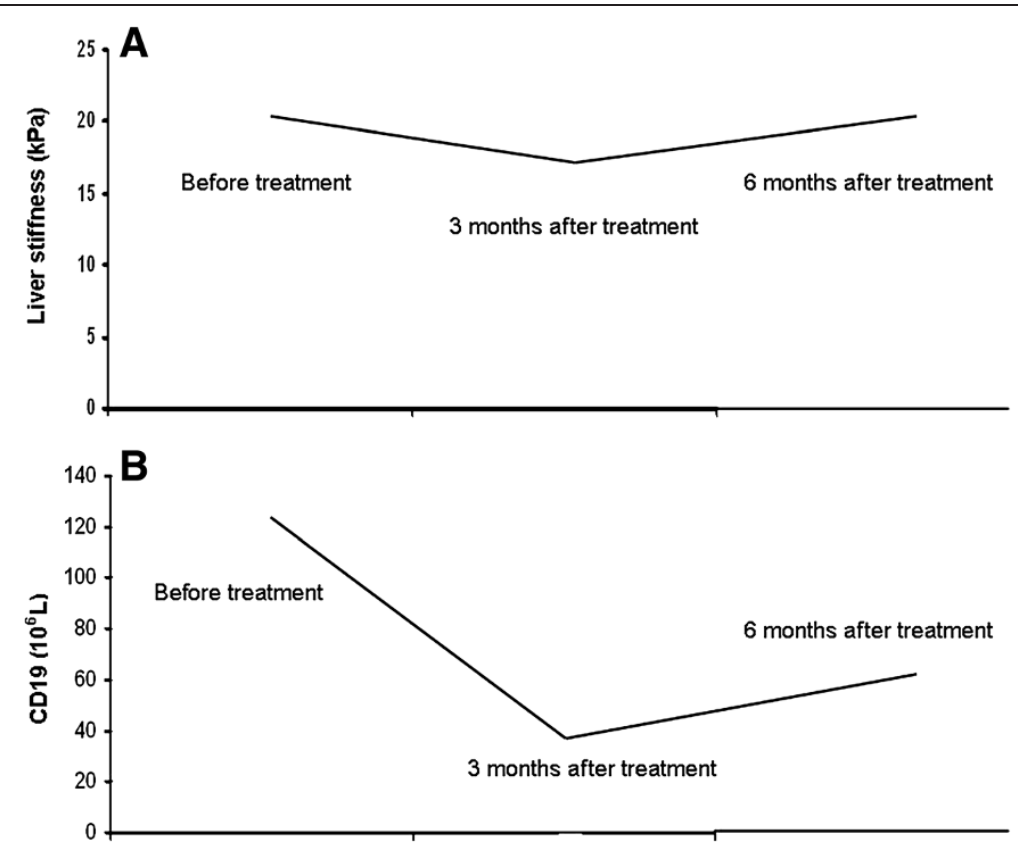

Figure 2 Changes of liver stiffness values and CD19+ cell levels at baseline, at three months and at six months after the end of treatment. Liver stiffness values (panel A) and CD19+ levels (panel B) were significantly different from those observed before treatment.

liver stiffness came back to the baseline levels $(\mathrm{p}=0.79)$ and the mean values of CD19+ gradually increased, even if they maintained a significant difference from those observed at baseline $(\mathrm{p}=0.04)$ (Figure 2). Also principal mixed cryoglobulinemia manifestations (clinical and biohumoral) improved at months 3 after therapy (Table 1).

\section{Discussion}

In the present study, for the first time, hepatic elastography was used to evaluate the liver stiffness values in HCVrelated MC patients undergoing RTX therapy and the liver stiffness modifications were shown to be related to the CD19+ depletion. In previous studies [16,17,30-33] TE was shown to be an effective technique on one side for diagnosing severe fibrosis or cirrhosis (F3 or F4 according to METAVIR scoring system [25]) and, on the other, for excluding a significant fibrosis, strongly suggesting that it may be a "diagnostic discriminator" to establish clinical priorities and reduce the number of liver biopsies. Moreover, TE was demonstrated to be characterized by high intra- and inter-observer repeatability [34,35]. In recent years, some methods such us serum markers of liver fibrosis, TE and magnetic resonance (MR) have been proposed as non-invasive, easily reproducible and acceptable by patients also for assessing progression/regression of liver fibrosis. However, only the morphologic alterations associated with cirrhosis are well visualized by ultrasound or MR imaging. These techniques do not visualize the precirrhotic stage of liver fibrosis and the early cirrhosis. In these conditions, the liver parenchyma appear normal in MR imaging, but the administration of contrast agents improves the visibility of fibrosis. In particular, double contrast-enhanced MR imaging causes high image contrast between the low-signal-intensity fibrotic reticulations. The main limitation of this technique is the high cost and the inconvenience related with the use of two contrasts [36].

Recently, some studies [18,37-41] evaluated the use of TE for the assessment of short- and long-term longitudinal changes in liver stiffness during and after antiviral treatment in patients with chronic HCV infection. The results of these studies validated these techniques also in a longitudinal evaluation of liver stiffness values for monitoring treatment response and in clinical management of $\mathrm{HCV}$ chronic liver disease. However, no data exist concerning HCV MC patients treated with RTX. In the present study, the liver stiffness of patients with chronic HCV infection and MC undergoing RTX treatment, decreased concomitantly with CD19+ cell levels, particularly at month 3 after the end of therapy, suggesting the pivotal role played by the degree of liver infiltrates and subsequent liver necro-inflammation. This is in agreement with previous studies $[16,17]$ showing that liver stiffness is influenced by necro-inflammatory activity. The important role played by $\mathrm{B}$ cells in both humoral and cellular immune response has been recently clarified $[42,43]$. Some studies $[44,45]$ showed that $\mathrm{CD} 19+\mathrm{CD} 24 \mathrm{hiCD} 27+\mathrm{B}$ cells regulate IFN $\gamma$ production by CD4+ T cells via IL-10-dependent pathways and TNF$\alpha$ production via IL-10 indipendent pathways. Antonelli 
et al. [46] in HCV-related MC showed significantly higher mean CXCL10 serum levels and TNF-alpha than HCV positive patients or controls. CXCL10 is secreted by the hepatocytes in inflammatory areas, and it recruits $\mathrm{T}$ cells to the hepatic lesions in chronic HCV infection [47]. Several studies [48-51] assessed the efficacy of RTX in patients with systemic sclerosis, because B cell play a key role in skin fibrogenesis [50,52]. The plateletderived growth factor (PDGF) stimulates fibroblast proliferation, with subsequent collagen production. The study of Daoussis et al. [51] in eight systemic sclerosis patients demonstrated significant decrease of fibrosis in all six patients that showed histologic improvement after six months of RTX treatment. In these patients, the expression of PDGF receptors significantly decreased following RTX administration. This also suggests a potential role of RTX in a block of liver fibrosis progression during treatment.

In the study by Petrarca et al. [15], after RTX treatment, Resovist-enhanced magnetic resonance imaging was used to quantify the involvement of Kupffer cells in the clearance of large circulating immune complexes in $\mathrm{MC}$. The authors showed that the iron signals were less than in healthy liver, but no evidence of significant modifications after RTX treatment were observed, suggesting that the improvement of cirrhotic syndrome was not consequence of an improved function of the reticuloendothelial system, but probably of the B cell depletion [15]. The results of the present study further support such an hypothesis.

Furthermore, concerning the potential risk of RTX treatment of patients with chronic viral infection, this study may confirm the safety of RTX in HCV patients with chronic liver disease. In fact, clinical/biohumoral parameters, including platelets, and albumine, in addition to liver stiffness, generally improved during therapy, thus confirming previous data $[13,15,42]$.

Rituximab led to a response rate of $25 \%$ in B-cell chronic lymphocytic leukemia (B-CLL) patients [53]. In these patients it would be interesting to study the correlation between $B$ cell expansion and liver stiffness in order to establish the effect of the drug on the liver.

In conclusion, this study for the first time showed that RTX-treatment in HCV MC and chronic liver damage induces a reduction of liver stiffness that is strictly associated with the B-cell depletion. This agrees with a previous observation [15] showing that RTX represents a safe and effective treatment of $\mathrm{HCV}$-related MC also in patients with severe liver disease. Further studies will be usefull to better clarify the role played by $\mathrm{B}$ cells not only in the pathogenesis of HCV-related MC, but also of liver damage.

\section{Abbreviations}

HCV: Hepatitis C virus; MC: Mixed cryoglobulinemia; MCS: Mixed cryoglobulinemia syndrome; NHL: Non-Hodgkin lymphoma;
Peg-IFN: Pegylated interferon; RBV: Ribavirin; RTX: Rituximab; TE: Transient elastography; F: Fibrosis; A: Necro-inflammatory activity; MR: Magnetic resonance.

\section{Competing interest}

The authors declare that they have no competing interest.

\section{Authors' contributions}

CS performed the research, collected and analysed the data, designed the research study and wrote the paper, ET performed the research and contributed to the drafting of the manuscript, UA, TU, AP performed the research and collected data, LG and GL revised it critically, ALZ contributed to the design and the writing of the paper and revised it critically. All authors read and approved the final manuscript.

Received: 8 October 2013 Accepted: 9 December 2013

Published: 24 January 2014

\section{References}

1. Zignego AL, Macchia D, Monti M, Thiers V, Mazzetti M, Foschi M, Maggi E, Romagnani S, Gentilini P, Bréchot C: Infection of peripheral mononuclear blood cells by hepatitis C virus. J Hepatol 1992, 15:382-386.

2. la Civita L, Zignego AL, Monti M, Longombardo G, Pasero G, Ferri C: Mixed cryoglobulinemia as a possible preneoplastic disorder. Arthritis Rheum 1995, 38:1859-1860.

3. Louer GM, Walker BD: Hepatitis C virus infection. N Engl J Med 2001, 345:41-52.

4. Craxì A, Laffi G, Zignego AL: Hepatitis C virus (HCV) infection: a systemic disease. Mol Aspects Med 2008, 29:85-95.

5. Ferri C, Greco F, Longombardo G: Association between hepatitis C virus and mixed cryoglobulinemia [see comment]. Clin Exp Rheumatol 1991, 9:621-624.

6. Agnello V, Chung RT, Kaplan LM: A role for hepatitis C virus infection in type II cryoglobulinemia [see comments]. N Engl J Med 1992, 327:1490-1495.

7. Zignego AL, Bréchot C: Extrahepatic manifestations of HCV infection: facts and controversies. J Hepatol 1999, 31:369-376.

8. Zignego AL, Ferri C, Pileri SA, Caini P, Bianchi FB: Extrahepatic manifestations of Hepatitis $C$ Virus infection: a general overview and guidelines for a clinical approach. Dig Liver Dis 2007, 39:2-17.

9. Ferri C, Sebastiani M, Giuggioli D, Cazzato M, Longombardo G, Antonelli A, Puccini R, Michelassi C, Zignego AL: Mixed cryoglobulinemia: demographic, clinical, and serologic features and survival in 231 patients. Semin Arthritis Rheum 2004, 33:355-374.

10. Monti G, Pioltelli P, Saccardo F, Campanini M, Candela M, Cavallero G, de Vita S, Ferri C, Mazzaro C, Migliaresi S, Ossi E, Pietrogrande M, Gabrielli A, Galli M, Invernizzi F: Incidence and characteristics of non-Hodgkin lymphomas in a multicenter case file of patients with hepatitis $C$ virus-related symptomatic mixed cryoglobulinemias. Arch Intern Med 2005, 165:101-105.

11. Ferri C, la Civita L, Cirafisi C, Siciliano G, Longombardo G, Bombardieri S, Rossi B: Peripheral neuropathy in mixed cryoglobulinemia: clinical and electrophysiologic investigations. J Rheumatol 1992, 19:889-895.

12. Pietrogrande $M$, de Vita S, Zignego AL, Pioltelli P, Sansonno D, Sollima S, Atzeni F, Saccardo F, Quartuccio L, Bruno S, Bruno R, Campanini M, Candela M, Castelnovo L, Gabrielli A, Gaeta GB, Marson P, Mascia MT, Mazzaro C, Mazzotta F, Meroni P, Montecucco C, Ossi E, Piccinino F, Prati D, Puoti M, Riboldi P, Riva A, Roccatello D, Sagnelli E: Recommendations for the management of mixed cryoglobulinemia syndrome in hepatitis $C$ virus-infected patients. Autoimmun Rev 2011, 10:444-454.

13. Ferri C, Cacoub P, Mazzaro C, Roccatello D, Scaini P, Sebastiani M, Tavoni A, Zignego AL, de Vita S: Treatment with rituximab in patients with mixed cryoglobulinemia syndrome: results of multicenter cohort study and review of the literature. Autoimmun Rev 2011, 11:48-55.

14. McLaughlin P, Grillo-Lopez AJ, Link BK, Levy R, Czuczman MS, Williams ME, Heyman MR, Bence-Bruckler I, White CA, Cabanillas F, Jain V, Ho AD, Lister J, Wey K, Shen D, Dallaire BK: Rituximab chimeric anti-CD20 monoclonal antibody therapy for relapsed indolent lymphoma: half of patients respond to a four-dose treatment program. J Clin Oncol 1998, 16:2825-2833

15. Petrarca A, Rigacci L, Caini P, Colagrande S, Romagnoli P, Vizzutti F, Arena U, Giannini C, Monti M, Montalto P, Matucci-Cerinic M, Bosi A, Laffi G, Zignego AL: 
Safety and efficacy of rituximab in patients with hepatitis $C$ virus-related mixed cryoglobulinemia and severe liver disease. Blood 2010, 116:335-342.

16. Arena U, Vizzuti F, Abraldes J, Corti G, Stasi C, Moscarella S, Milani S, Lorefice E, Petrarca A, Romanelli RG, Laffi G, Bosch J, Marra F, Pinzani M: Reliability of transient elastography for the diagnosis of advanced fibrosis in chronic hepatitis C. Gut 2008, 57:1288-1293.

17. Stasi C, Arena U, Vizzutti F, Zignego AL, Monti M, Laffi G, Corti G, Pinzani M: Transient elastography for the assessment of liver fibrosis in patients with chronic viral hepatitis: the missing tool? Dig Liver Dis 2009, 41:863-866.

18. Stasi C, Arena U, Zignego AL, Corti G, Monti M, Triboli E, Pellegrini E, Renzo S, Leoncini L, Marra F, Laffi G, Milani S, Pinzani M: Longitudinal assessment of liver stiffness in patients undergoing antiviral treatment for hepatitis $C$. Dig Liver Dis 2013, 45:840-843.

19. Coco B, Olivieri F, Maina AM, Ciccorossi P, Sacco R, Colombatto P, Bonino F, Brunetto MR: Transient elastography: a new surrogate marker of liver fibrosis influenced by major changes of transaminases. J Viral Hepat 2007, 14:360-369

20. Sagir A, Erhardt A, Schmitt M, Häussinger D: Transient elastography is unreliable for detection of cirrhosis in patients with acute liver damage. Hepatology 2008, 47:592-595.

21. de Vita S, Quartuccio L, Isola M, Mazzaro C, Scaini P, Lenzi M, Campanini M, Naclerio C, Tavoni A, Pietrogrande M, Ferri C, Mascia MT, Masolini P, Zabotti A, Maset M, Roccatello D, Zignego AL, Pioltelli P, Gabrielli A, Filippini D, Perrella O, Migliaresi S, Galli M, Bombardieri S, Monti G: A randomized controlled trial of rituximab for the treatment of severe cryoglobulinemic vasculitis. Arthritis Rheum 2012, 64:843-853.

22. Zignego AL, Giannelli F, Marrocchi ME, Mazzocca A, Ferri C, Giannini C, Monti M, Caini P, Villa GL, Laffi G, Gentilini P: T $(14 ; 18)$ translocation in chronic hepatitis $C$ virus infection. Hepatology 2000, 31:474-479.

23. Zignego AL, Ferri C, Giannini C, Monti M, la Civita L, Careccia G, Longombardo G, Lombardini F, Bombardieri S, Gentilini P: Hepatitis C virus genotype analysis in patients with type II mixed cryoglobulinemia. Ann Intern Med 1996, 124:31-34.

24. Andreone P, Zignego AL, Cursaro C, Gramenzi A, Gherlinzoni F, Fiorino S, Giannini C, Boni P, Sabattini E, Pileri S, Tura S, Bernardi M: Prevalence of monoclonal gammopathies in patients with hepatitis $C$ virus infection. Ann Intern Med 1998, 129:294-298.

25. Bedossa P, Poynard T: An algorithm for the grading of activity in chronic hepatitis C. The METAVIR Cooperative Study Group. Hepatology 1996, 24:289-293.

26. Gaiani S, Gramantieri L, Venturoli N, Piscaglia F, Siringo S, D’Errico A, Zironi G, Grigioni W, Bolondi $L$ : What is the criterion for differentiating chronic hepatitis from compensated cirrhosis? A prospective study comparing ultrasonography and percutaneous liver biopsy. J Hepatol 1997, 27:979-985.

27. Pugh RN, Murray-Lyon IM, Dawson JL, Pietroni MC, Williams R: Transection of the oesophagus for bleeding oesophageal varices. Br J Surg 1973, 60:646-649

28. Guido M, Rugge M: Liver fibrosis: natural history may be affected by the biopsy sample. Gut 2004, 53:1878.

29. Piluso A, Giannini C, Fognani E, Gragnani L, Caini P, Monti M, Petrarca A, Ranieri J, Urraro T, Triboli E, Laffi G, Zignego AL: Value of IL28B genotyping in patients with HCV-related mixed cryoglobulinemia: results of a large, prospective study. J Viral Hepat 2013, 20:e107-e114.

30. Ziol M, Handra-Luca A, Kettaneh A, Christidis C, Mal F, Kazemi F, de Lédinghen V, Marcellin P, Dhumeaux D, Trinchet JC, Beaugrand M: Noninvasive assessment of liver fibrosis by measurement of stiffness in patients with chronic hepatitis $C$. Hepatology 2005, 41:48-54.

31. Castera L, Vergniol J, Foucher J, le Bail B, Chanteloup E, Haaser M, Darriet M, Couzigou P, de Lédinghen V: Prospective comparison of transient elastography, Fibrotest, APRI, and liver biopsy for the assessment of fibrosis in chronic hepatitis C. Gastroenterology 2005, 128:343-350.

32. Sandrin L, Fourquet B, Hasquenoph JM, Yon S, Fournier C, Mal F, Christidis C, Ziol M, Poulet B, Kazemi F, Beaugrand M, Palau R: Transient elastography: a new noninvasive method for assessment of hepatic fibrosis. Ultrasound Med Biol 2003, 29:1705-1713.

33. Foucher J, Chanteloup E, Vergniol J, Castéra L, le Bail B, Adhoute X, Bertet J, Couzigou $P$, de Lédinghen V: Diagnosis of cirrhosis by transient elastography (FibroScan): a prospective study. Gut 2006, 55:403-408.

34. Fraquelli M, Rigamonti C, Casazza G, Conte D, Donato MF, Ronchi G, Colombo M: Reproducibility of transient elastography in the evaluation of liver fibrosis in patients with chronic liver disease. Gut 2007, 56:968-973.
35. Nobili V, Vizzutti F, Arena U, Abraldes JG, Marra F, Pietrobattista A, Fruhwirth R, Marcellini M, Pinzani M: Accuracy and reproducibility of transient elastography for the diagnosis of fibrosis in pediatric nonalcoholic steatohepatitis. Hepatology 2008, 48:442-448.

36. Aguirre DA, Behling CA, Alpert E, Hassanein TI, Sirlin CB: Liver fibrosis: noninvasive diagnosis with double contrast material-enhanced MR imaging. Radiology 2006, 239:425-437.

37. Ogawa E, Furusyo N, Toyoda K, Takeoka H, Maeda S, Hayashi J: The longitudinal quantitative assessment by transient elastography of chronic hepatitis $C$ patients treated with pegylated interferon alpha- $2 \mathrm{~b}$ and ribavirin. Antiviral Res 2009, 83:127-134.

38. Arima $Y$, Kawabe $N$, Hashimoto $S, R$ Harata M, Nitta $Y$, Murao M, Nakano T, Shimazaki H, Kobayashi K, Ichino N, Osakabe K, Nishikawa T, Okumura A, Ishikawa T, Yoshioka K: Reduction of liver stiffness by interferon treatment in the patients with chronic hepatitis C. Hepatol Res 2010, 40:383-392.

39. Macías J, del Valle J, Rivero A, Mira JA, Camacho A, Merchante N, Pérez-Camacho I, Neukam K, Rivero-Juárez A, Mata R, Torre-Cisneros J, Pineda JA, Grupo para el Estudio de las Hepatitis Víricas de la Sociedad Andaluza de Enfermedades Infecciosas: Changes in liver stiffness in patients with chronic hepatitis $C$ with and without HIV co-infection treated with pegylated interferon plus ribavirin. J Antimicrob Chemother 2010, 65:2204-2211.

40. Wang $\mathrm{JH}$, Changchien $\mathrm{CS}$, Hung $\mathrm{CH}$, Tung WC, Kee KM, Chen $\mathrm{CH}$, Hu TH, Lee CM, Lu SN: Liver stiffness decrease after effective antiviral therapy in patients with chronic hepatitis C: Longitudinal study using FibroScan. J Gastroenterol Hepatol 2010, 25:964-969.

41. Martinez SM, Foucher J, Combis JM, Métivier S, Brunetto M, Capron D, Bourlière M, Bronowicki JP, Dao T, Maynard-Muet M, Lucidarme D, Merrouche W, Forns $X$, de Lédinghen $V$ : Longitudinal liver stiffness assessment in patients with chronic hepatitis $C$ undergoing antiviral therapy. PLoS One 2012, 7:e47715.

42. Yuseff MI, Pierobon P, Reversat A, Lennon-Duménil AM: How B cells capture, process and present antigens: a crucial role for cell polarity. Nat Rev Immunol 2013, 13:475-486.

43. Leandro MJ, de la Torre I: Translational minireview series on B cell-directed therapies: the pathogenic role of $B$ cells in autoantibodyassociatedautoimmune diseases-lessons from B cell depletion therapy. Clin Exp Immunol 2009, 157:191-197.

44. Zha B, Wang L, Liu X, Liu J, Chen Z, Xu J, Sheng L, Li Y, Chu Y: Decrease in proportion of CD19+ CD24(hi) CD27+ B cells and impairment of their suppressive function in Graves' disease. PLoS One 2012, 7:e49835.

45. Iwata Y, Matsushita T, Horikawa M, Dilillo DJ, Yanaba K, Venturi GM, Szabolcs PM, Bernstein SH, Magro CM, Williams AD, Hall RP, St Clair EW, Tedder TF: Characterization of a rare IL-10-competent B-cell subset in humans that parallels mouse regulatory B10 cells. Blood 2011, 117:530-541.

46. Antonelli A, Ferri C, Fallahi P, Ferrari SM, Sebastiani M, Ferrari D, Giunti M, Frascerra S, Tolari S, Franzoni F, Galetta F, Marchi S, Ferrannini E: High Values of CXCL10 Serum Levels in Mixed Cryoglobulinemia Associated With Hepatitis C Infection. Am J Gastroenterol 2008, 103:2488-2494.

47. Harvey CE, Post JJ, Palladinetti P, Freeman AJ, Ffrench RA, Kumar RK, Marinos G, Lloyd AR: Expression of the chemokine IP-10 (CXCL10) by hepatocytes in chronic hepatitis $C$ virus infection correlates with histological severity and lobular inflammation. J Leukoc Biol 2003, 74(3):360-369.

48. Lafyatis R, Kissin E, York M, Farina G, Viger K, Fritzler MJ, Merkel PA, Simms RW: $B$ cell depletion with rituximab in patients with diffuse cutaneous systemic sclerosis. Arthritis Rheum 2009, 60:578-583.

49. Smith V, van Praet JT, Vandooren B, van der Cruyssen B, Naeyaert JM, Decuman S, Elewaut D, de Keyser F: Rituximab in diffuse cutaneous systemic sclerosis: an open-label clinical and histopathological study. Ann Rheum Dis 2010, 69:193-197.

50. Hasegawa M, Hamaguchi Y, Yanaba K, Bouaziz JD, Uchida J, Fujimoto M, Matsushita T, Matsushita Y, Horikawa M, Komura K, Takehara K, Sato S, Tedder TF: B-lymphocyte depletion reduces skin fibrosis and autoimmunity in the tight-skin mouse model for systemic sclerosis. Am J Pathol 2006, 169:954-966.

51. Daoussis D, Tsamandas AC, Liossis SN, Antonopoulos I, Karatza E, Yiannopoulos G, Andonopoulos AP: B-cell depletion therapy in patients with diffuse systemic sclerosis associates with a significant decrease in PDGFR expression and activation in spindle-like cells in the skin. Arthritis Res Ther 2012, 14:R145. 
52. Saito E, Fujimoto M, Hasegawa M, Komura K, Hamaguchi $Y$, Kaburagi $Y$, Nagaoka T, Takehara K, Tedder TF, Sato S: CD19-dependent B lymphocyte signaling thresholds influence skin fibrosis and autoimmunity in the tight-skin mouse. J Clin Invest 2002, 109:1453-1462.

53. Huhn D, von Schilling C, Wilhelm M, Ho AD, Hallek M, Kuse R, Knauf W, Riedel U, Hinke A, Srock S, Serke S, Peschel C, Emmerich B, German Chronic Lymphocytic Leukemia Study Group: Rituximab therapy of patients with B-cell chronic lymphocytic leukaemia. Blood 2001, 98(5):1326-1331.

doi:10.1186/1479-5876-12-21

Cite this article as: Stasi et al:: Assessment of liver stiffness in patients with HCV and mixed cryoglobulinemia undergoing rituximab treatment. Journal of Translational Medicine 2014 12:21.

\section{Submit your next manuscript to BioMed Central and take full advantage of:}

- Convenient online submission

- Thorough peer review

- No space constraints or color figure charges

- Immediate publication on acceptance

- Inclusion in PubMed, CAS, Scopus and Google Scholar

- Research which is freely available for redistribution 